\title{
SCIENCE AND POLITICAL IDEOLOGY The example of Nazi Germany
}

\section{UTE DEICHMANN}

Although in their basic framework Nazi anti-Semitic and racist ideology and policies were not grounded in science, scientists not only supported them in various ways, but also took advantage of them, for example by using the new possibilities of unethical experimentation in humans that these ideologies provided. Scientists' complicity with Nazi ideology and politics does, however, not mean that all sciences in Nazi Germany were ideologically tainted. I argue, rather, that despite the fact that some areas of science continued at high levels, science in Nazi Germany was most negatively affected not by the imposition of Nazi ideology on the conduct of science but by the enactment of legal measures that ensured the expulsion of Jewish scientists. The anti-Semitism of young faculty and students was particularly virulent. Moreover, I show that scientists supported Nazi ideologies and policies not only through so-called reductionist science such as eugenics and race-hygiene, but also by promoting organicist and holistic ideologies of the racial state.

Keywords: academic anti-Semitism, ecology and holism in Nazi Germany, science and values.

\section{INTRODUCTION}

The last decades have seen a strong resurgence in anti-Semitism and racism in Western countries that has been prompted, among other things, by the arrival of large numbers of refugees and other non-European migrants in Europe. The ultranationalism, racism, and homophobia prevalent in the far right are reminiscent of Nazi (and other fascist) ideologies. However, the rising anti-Semitism, sometimes couched in terms of antiZionism and prevalent in leftist organizations, raises questions regarding its ideological origins as well.

An ongoing retrospective on the intricate relationship between science and Nazi racial and anti-Semitic ideologies shows that (I) though these ideologies were not scientific in nature, they were frequently supported by scientists violating existing ethical norms; (II) this fact does not imply that all sciences are at any time politicized or inseparable from ideology; (III) combatting these ideologies today should not be a matter of changing scientific maxims, but of emphasizing the ethical principles and their implementation in our societies as wholes.

\section{SCIENCE AND IDEOLOGY IN NAZI GERMANY}

In 1941, Sir Richard Gregory, former editor of Nature, pointed to the danger of basing the conduct of science on principles other than scientific ones: «To make race, political convictions, or religious faith, barriers to the pursuit of natural knowledge, means that science in Nazi Germany loses its soul for the purpose of gaining the world» (cited in Deichmann, 2000). Six years later, Max Delbrück, a German-born physicist and geneticist then resident in the United States, was preparing to visit Germany. The American geneticist Hermann Muller asked him to find out which German geneticists had never voluntarily helped the Nazi regime. This information, he suggested, «would be very helpful to our Committee on Aid to Geneticists Abroad, because many of the members... do not want 


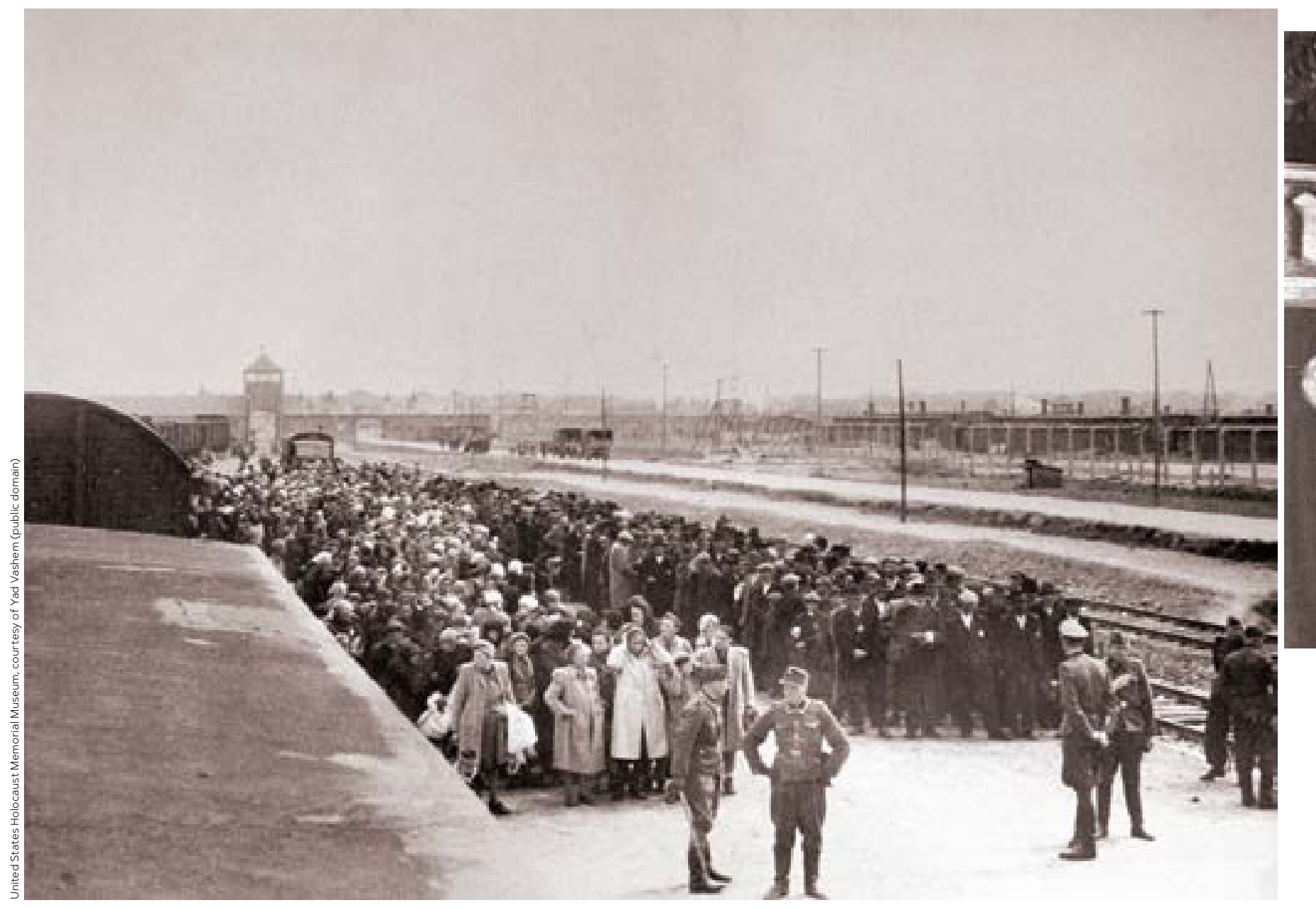

Measures such as the forced sterilization of the genetically unfit were grounded in science, the racist and anti-Semitic frameworks of Nazi ideology and practice were not. So we cannot search for the scientific rationale behind the deportation and extermination of the Jews in Nazi ideology and policies. The photograph shows Jews lined up for selection on the ramp at the Auschwitz-Birkenau camp in May 1944.

to have their money used to help people who had taken part in the prostitution of science or in the movement that would have destroyed the values for which civilization should stand» (Deichmann, 1996, p. 312).

Muller and Gregory were responding to the existence of a scientific ethos that was violated by scientists in Nazi Germany. They believed that science is not, or should not be, ideologically influenced but should proceed according to its own rules and maxims; therefore, scientists' ideological and practical support of Nazi race policy can be called prostitution. They also believed that universality, i.e., independence of national or ethnic affiliations, is a core scientific principle.

These views, idealistic as they may sound today, relate to principles that, together with special methodologies and epistemologies, have enabled science to become the authority of knowledge that is far superior and more reliable than that generated by any other human activity. The fact that scientists throughout the centuries, and in particular in totalitarian regimes, not only proceeded along scientific maxims, but were also influenced by prevailing ideologies, has not prevented the generation of an increasing body of universal, well-grounded scientific knowledge. The discovery of nuclear fission and the synthesis of the nerve gases tabun and sarin in Nazi Germany are examples of the potential power created through scientific activities in totalitarian regimes as well. For this reason, the current trend to regard all sciences as entrenched in political ideology and to deny their privileged status in generating knowledge is dangerous. It relativizes the actual power scientific results can have in the hands of engineers and politicians, especially in inhuman regimes, and it exculpates scientists who voluntarily support immoral ideologies and practices with their work and prestige.

As has been abundantly documented, scientists in Nazi Germany, often not under political pressure, violated existing ethical principles and supported 


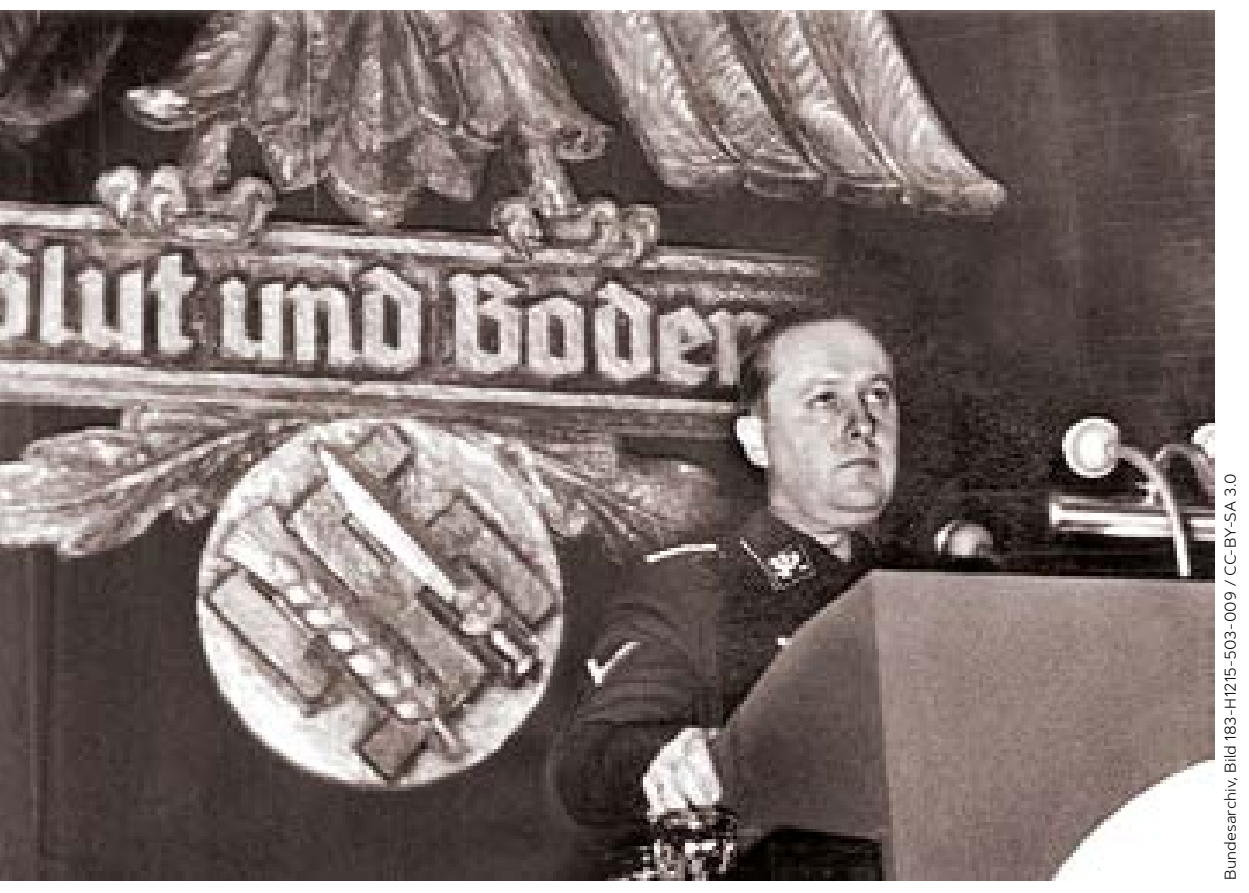

Different groups of Nazi party ideologues and politicians, for example the Minister of Agriculture Walther Darré, a blood and soil ideologue, had different concepts of race and racial changes in human evolution that never became scientifically binding. In the photograph, Darré in 1937 addresses during a political rally in Goslar, with the slogan "Blut und Boden" ("blood and soil") in the background.

Nazi racist and imperialist aims in manifold ways, e.g., as plant-breeders, who pursued the breeding of crop varieties adapted to the conditions of the occupied territories in the «East» (i.e., Poland or the Soviet Union); psychiatrists who decided on murdering patients through euthanasia; anthropologists who drew up expert opinions of «racial» memberships in connection with the Nuremberg laws (often only based on photographs of possible fathers); chemists, who conducted war-related research including on chemical warfare; and medical scientists who carried out often fatal experiments on concentration camp inmates with the aim of providing treatment or vaccination for soldiers, to name just a few.

However, the fact that many scientists supported Nazi ideologies and policies does not mean that they created them. Thus, though individual measures such as the forced sterilization of the «genetically unfit» were grounded in science, the racist and anti-Semitic frameworks of Nazi ideology and practice certainly were not. But the eugenic sterilization law, though it was extreme in its application compared to similar laws in other countries, including the US, was not aimed at particular races, and it was not, as was claimed for example by historian Robert W. Sussman (2014), the rationale behind the deportation and extermination of the Jews.

The ideology of leading Nazi party ideologues was strongly influenced by the Volkish movement which, in the wake of the writings of philosopher Johann Gottlieb Fichte and other nineteenth century authors, promoted the idea of Volk (people) as an organic unity. They did not base their virulent anti-Semitism and racism on anthropological concepts. In the Nazi era, different groups of Nazi party ideologues and politicians, for example the Minister of Agriculture Walther Darré, a blood and soil ideologue, or the founder of the virulently anti-Semitic newspaper Der Stürmer, Julius Streicher, had different concepts of race and racial changes in human evolution that never became scientifically binding (e.g., Deichmann, 1996, 251-276; Wetzell 2017); and anthropologists did not speak of a Jewish or «Aryan» race in their scientific publications (Hutton 2005, p. 48, pp. 80-100). But scientists became accomplices of Nazi racial policy. In the words of Benno Müller-Hill on human geneticists, they «had to accept and support the violent antiSemitism of the Nazis in order to be rewarded with positions and ample support for research on hereditary diseases. They did so» (Müller-Hill, 1988).

Nazi race ideology impacted the sciences in Germany in many different ways. Its most negative impact on the conduct of science was through the dismissal and forced emigration of Jewish scientists and scholars.

\section{THE IMPACT OF THE EXPULSION OF JEWISH SCIENTISTS}

The purge of all Jewish scientists and those of Jewish extraction from German academia, one of the first anti-Jewish measures, was based on laws and decrees, the most important being the Law for the Restoration 


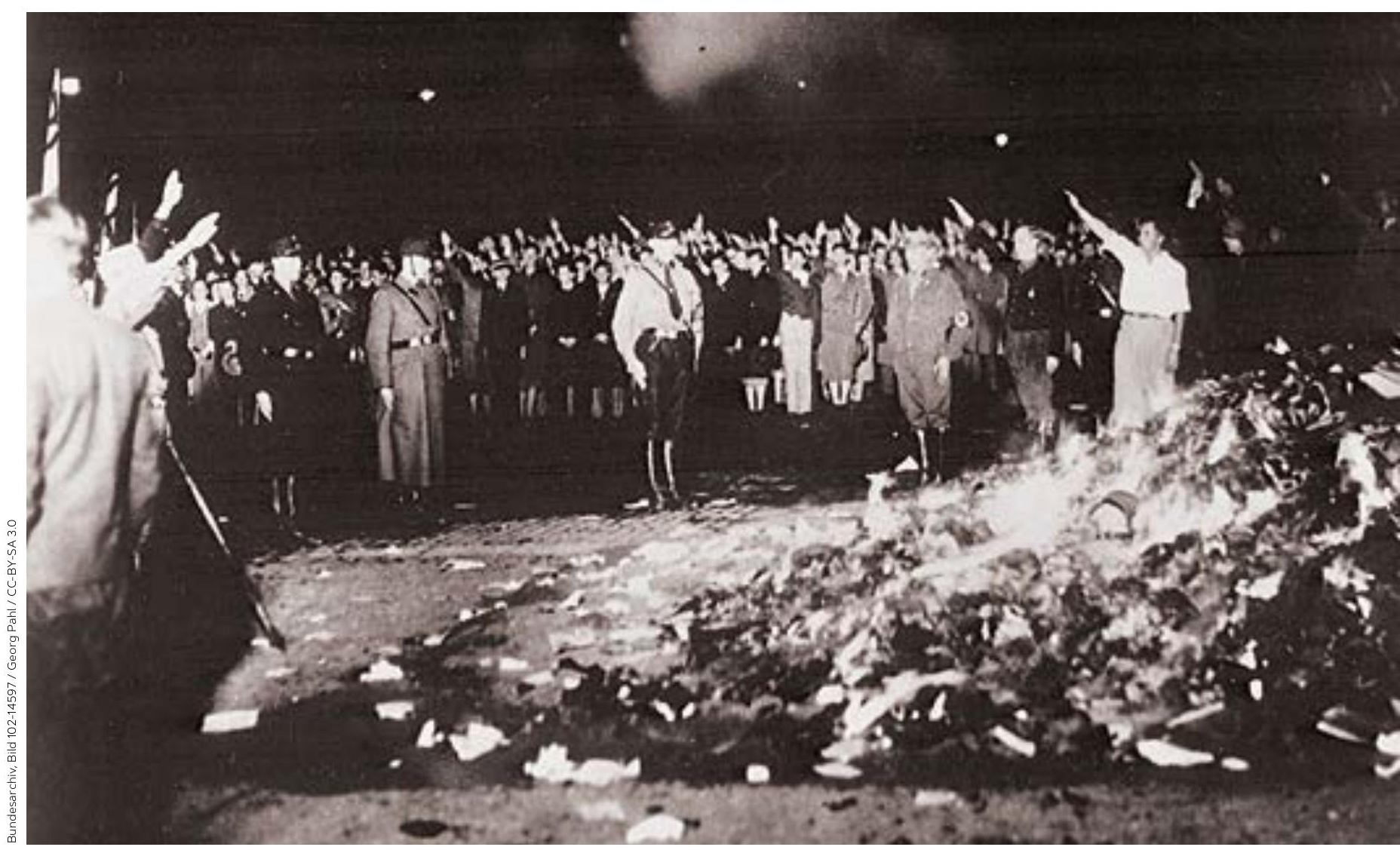

Burning of «un-German» books by university students in Berlin on 10 May 1933. It was the students and their organizations who were the carriers of the called "National Socialist revolution» at universities. They identified for example Jewish graduate students whom professors had permitted to complete their Ph.D., or Jewish professors who as former front-line soldiers were permitted to stay in their position (until 1935), and campaigned for their dismissal.

of the Professional Civil Service of April 7, 1933. Jews were identified through the religious affiliation of their grandparents; the category «Mischling» (halfbreed) included people with one Jewish grandparent, which was sufficient for dismissal.

This purge had far-reaching consequences for many sciences (Bergmann, Epple, \& Ungar, 2012; Deichmann, 1996, 1999, 2001). Following the legal emancipation of Jews in Germany in 1870, Jewish scientists and scholars were admitted to academic positions and became prominent in such fields as biochemistry, chemistry, mathematics, the classics, and law. The reasons for their disproportionately high participation in academia and for their uneven distribution and uneven success in various fields were analyzed elsewhere (Charpa \& Deichmann, 2007). Suffice it here to say that because of the high and uneven participation of Jewish scientists in different fields, the anti-Semitic laws had severe effects on research and teaching in general and on some fields in particular. With $25 \%$ of dismissals and/ or emigrations of university teachers and researchers in Kaiser Wilhelm Institutes, chemistry was strongly affected; of the chemical sub-disciplines, physical chemistry had the highest losses (36\%) (Deichmann, 1999, 2001). Biochemistry and mathematics each had a loss of around 33\% (Bergmann et al., 2012; Deichmann, 1999, 2001), whereas biology, i.e., zoology, botany, and non-human genetics, was less affected $(8 \%)$. Physics ranked somewhere in the middle; there are no clear figures. Next to mathematics it was German biochemistry which lost its most prominent researchers, among them several present and future Nobel Prize laureates.

This loss was a major reason for the decline of the formerly world renowned German biochemistry and also contributed to the delayed beginning of molecular biology in Germany after World War II. The high scientific achievements of many of the émigrés contributed to raising the scientific standards in the countries of refuge, in particular the US, UK, and Turkey, as expressed by Harvard University 

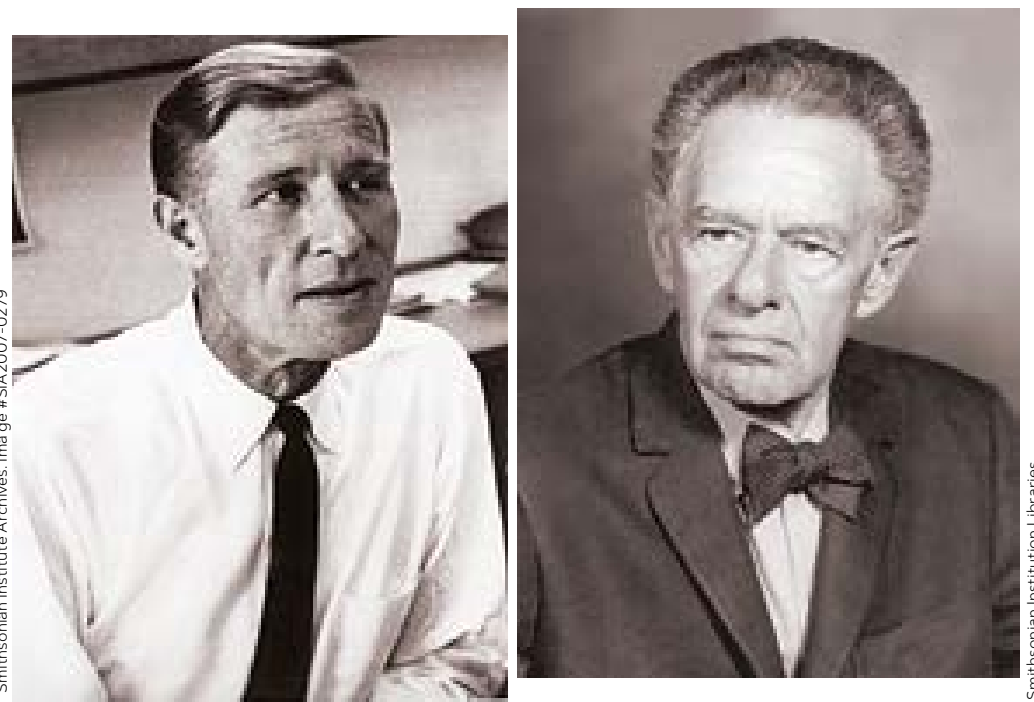

2001). While established academic staff were not openly anti-Semitic before 1933 and in many cases Jewish scientists had friendly relationships with non-Jewish colleagues, a virulent anti-Semitism, prevalent among younger staff, and in particular among students, had been in evidence since the 1920s. It was the students and their organizations who were the carriers of the «National Socialist revolution»-an official term at the time - at universities. They identified Jewish graduate students whom professors had permitted to complete their Ph.D., or Jewish

German biochemistry lost its most prominent researchers because of the expulsion of Jewish scientists from Germany. In the photographs, biochemists Konrad Bloch (left) in 1964, the year he received the Nobel Prize in Physiology or Medicine, and Fritz Lipmann (right), who was awarded the Nobel Prize in 1953. Both were driven out of Germany by the Nazi regime.

biochemist Eugene Kennedy (2001, p. 42619): «Before the Second World War, biochemistry in the United States had a strong flavor of clinical chemistry. [...] American students had to go abroad to Germany or to England for training in what came to be called dynamic aspects of biochemistry. After the war, the flow of students was largely reversed. This transformation was, in considerable part, the result of new insights and new approaches brought to America by immigrant scientists.»

It is one of the most notable phenomena in academia in 1933 that the severest measures of Nazi policies against science, the expulsion of Jewish scientists, were carried out under a high degree of silence and with the frequent consensus of their nonJewish colleagues. Despite the fact that most Jews identified themselves with the German nation and culture, there were not only no public protests, but also hardly any private ones or signs of compassion.

Elsewhere, I have explained this silence and lack of solidarity with obedience to the law (the dismissals were ordered by law, and most German scientists were civil servants, i.e., obliged to obey the law), self-benefit (as most vacancies were quickly filled by younger staff, who were often members of Nazi organizations) and anti-Semitism (Deichmann, 1999, professors who as former front-line soldiers were permitted to stay in their position (until 1935), and campaigned for their dismissal. Looking at the current rise of anti-Semitism world-wide, including in academia, it is remarkable that most anti-Semitic campaigns and incidents at European and NorthAmerican universities are also brought about by students and their organizations. Though the reasons today are certainly different from those driving antiSemitism in the 1930s, it is important to remember their devastating consequences.

\section{THE EMERGENCE OF «POLITICAL ECOLOGY»}

The rationales behind the anti-Jewish policies and the persecution of other people deemed not fit to the notion of a healthy German race, such as Gypsies and homosexuals, were imbedded in the ideology of wholeness and an ultranationalism prevalent among leading Nazi party ideologues. They attempted to replace scientific internationalism, regarded as the manifestation of past liberal and Jewish ways of thinking, with the nationalist ideology that science, too, was a product of blood, i.e., that German science was different than Jewish science. As is well-known, this ideology provided for some years a niche for the movement for «German» or «Aryan physics» that had been launched in the 1920s by the two Nobel laureates of physics Philipp Lenard and Johannes Stark. Rejecting the high level of abstraction and mathematics of theoretical physics and relativity theory as result of 
the Jewish way of thinking, which they contrasted with the visualizable (anschaulich) and pragmatic way of German thinking, the movement gained support predominantly from young faculty and representatives of the Nazi student movement (Beyerchen, 1977). Nevertheless, it lost its power after a few years, and in 1940 the Nazi party officially restored the reputation of theoretical physics. This movement and a few other attempts to ideologically transform the sciences did not succeed to forcefully change the contents of most of the basic research. This was unlike in the USSR under Lysenko, where several sciences, in particular genetics, were suppressed for decades, and dissenting scientists persecuted and murdered (see for example Joravsky, 1970).

The ideology of «wholeness» was, however, promoted by biologists who voluntarily politicized the rhetoric of their science, in part for opportunistic reasons, in part, because they believed in the ideology. Ecology is a case in point.

The politicization of ecology in Germany started already in the 1920 s, when teleological and organismic concepts - based on the notion that a specific environment determines a specific biocoenosis, which behaves as an organism in its own right- soon took precedence over individualistic concepts. According to the latter, there are no organismic units above organisms, but only more or less coincidental associations. The organismic ecological concept had a strong relation with holism, a philosophical outsider concept founded by the South African J. C. Smuts that was usually accompanied by political conservatism. This held true not only for ecologists in Germany but also in other countries, particularly the US (Trepl, 1987, p. 148).

The «völkische Bewegung» ("volkish movement") was another reason for the politicization of ecology. One of these nationalistic organizations (Artamen) in the 1920s had developed the concept of «blood and soil» (Bramwell, 1985), an anti-Semitic and anti-Slavic concept that was originally aimed at maintaining German people in rural areas and preventing Polish immigrants from working at east German farms. Later it was adopted by Heinrich Himmler and the SS and implied the «solving of the Jewish question» that is the murder of all European Jews and the expulsion of millions of east Europeans from their homes.
The activities of the entomologist Karl Friederichs, who since the 1920s developed theoretical ecological concepts, emphasizing the self-regulatory achievement of an ecological system with the goal of a biocoenotic balance, demonstrates the politicization of ecology most clearly. In 1934, he stressed his notion of goal-oriented teleological processes that lead to the preservation of a norm in nature, still in a non-political way, though political allusions were palpable. Referring to the holist Adolf Meyer, he claimed that «teleological thinking» was a prerequisite for «understanding the organism and its environment as a living and harmonious whole». Therefore, ecology was a path «to the total world view, a view of the world in which everything is related to everything else, everything directly or indirectly affects everything else, and in which everything is simultaneously in motion and in a process of transformation» (Friederichs, 1934).

Three years later, Friederichs explicitly regarded his striving towards the «spreading of ecological thinking» as a contribution to Nazi ideology and politics: «Such an effort of the ecologist towards raising the consciousness of nature among the population would be useless if it were not entirely in agreement with the current of time, especially the political one» (Friederichs, 1937, p. 86). He quoted Hitler (without a source reference) as having said that man should never believe in having become the master of nature but instead must understand the necessity of the processes in nature. Friederichs summarized succinctly: «Ecology is the doctrine of blood and soil» (Friederichs, 1937, p. 91).

Other biologists, most notably the zoologist Hermann Weber, repeated this notion of a political ecology and biology. According to him, a new era had begun, in which biology had become a crucial science (Weber, 1935). «For us Germans», he said, «speed and direction of the march into the new era has been determined by Adolf Hitler's movement». He regarded biology not only as an essential part of the new era, but held that, «for us Germans it is also the foundation of a new political attitude». Biology, Weber concluded, teaches everybody «that life in a community has to be thought of as organismic, and holistic». In a higher and new meaning, biology has become «a political science» (Weber, 1935). In 1942, when the deportations of Jews were apparent 


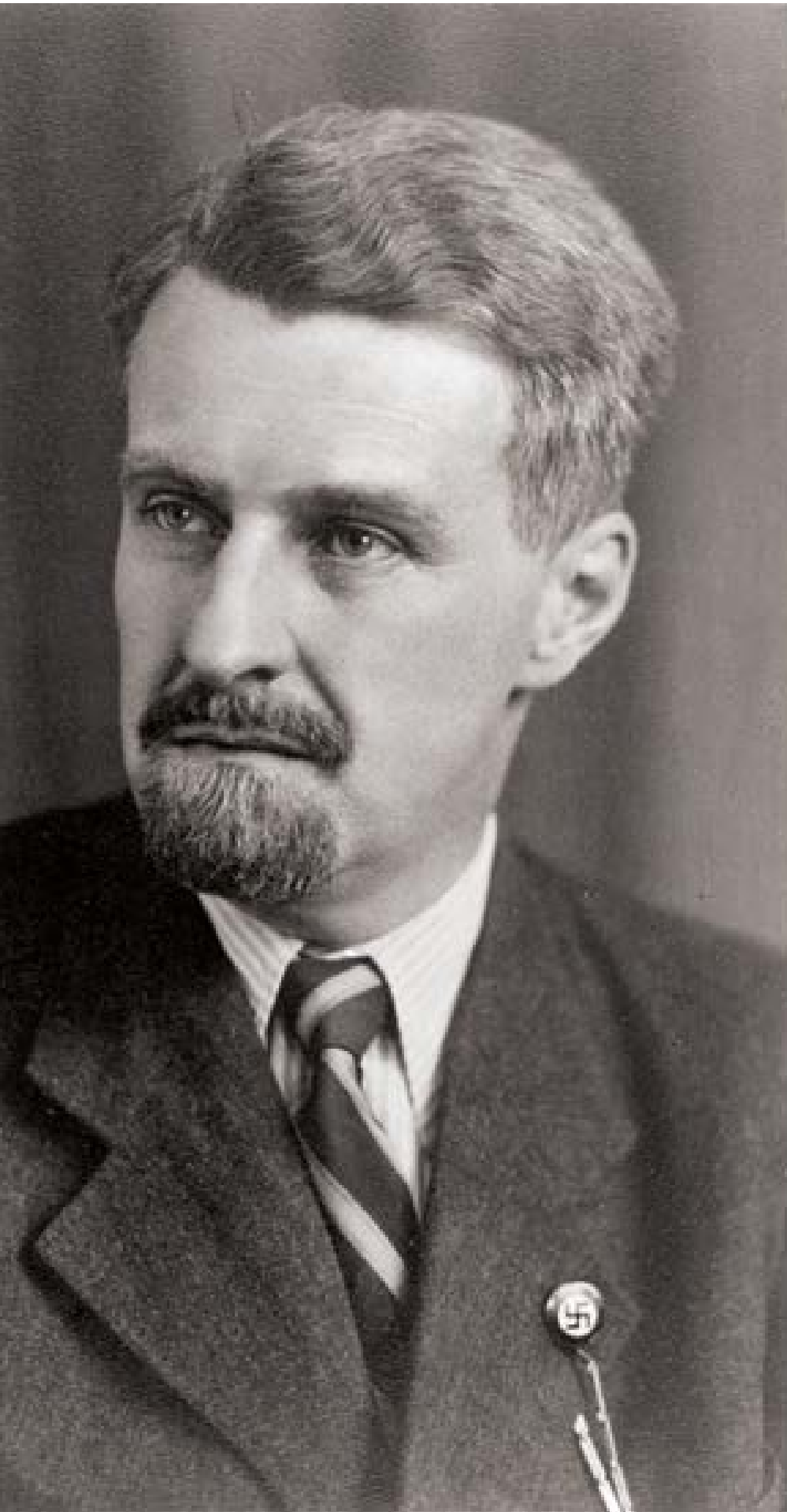

In 1973, Konrad Lorenz received the Nobel Prize in Physiology or Medicine. In the 1940s, Konrad, a member of the Office of Racial Policy of the NSDAP, had demanded that a «scientifically underpinned race policy" eradicate inferior elements from society. In the picture, a 1940 photograph shows Lorenz with the Nazi pin in his lapel. to everybody, Weber equated the biological term «organism and environment» with the term «blood and soil» in politics (Weber, 1942).

The results of the «policy of blood and soil» are well known. As stated before, the concepts of unity, wholeness, and organicism were central to Nazi race ideology. The head of the Office of Race Policy of the NSDAP, ${ }^{1}$ Walter Gross, pointed out in 1936: «The basic thought of race policy results from the consciousness of unity and wholeness of life. This claim of totality bridges the gap between matter and spirit, and it abolishes at the same time the idea of this dualism. [...] By that, race doctrine does not appear as part of another science, but embraces the wholeness of life; it never remains with the particular, but creates out of itself the total world view, compulsory to the very end for any National Socialist» (Deichmann, 2004). The unity and wholeness of the German people required the exclusion of all peoples considered of foreign races, in particular Jews, and of those with hereditary diseases. Thus, the concepts of wholeness and organicism in Nazi Germany were closely related to the concept of «cleansing» from undesirable people, first by denying them basic rights, then by elimination.

\section{«Konrad Lorenz had demanded that a "scientifically underpinned race policy" eradicate inferior elements from society»}

When, starting in the 1980s, scholars and social movements began to critically reflect on scientists' complicity with Nazi racial atrocities in Germany and elsewhere, geneticists and reductionism were widely criticized, whereas the closeness of the ideologies of organicism and holism to race ideology was anathema to most movements and commentators. The WestGerman environmental movement of the 1980s cited the 1959 new edition of Karl Friederichs's 1937 book in order to support the appeal for ecology as a unifying (not interdisciplinary) natural science, on which the development of a new scientific era should be based, which should replace the era of causal reductionist science (Trepl, 1987, p. 17). According to political scientist and writer Peter Cornelius Mayer-Tasch (1985, p. 9), «political ecology will [most probably] become the guiding science of post-modernism in a similar way as the enlightened scientism had been

\footnotetext{
${ }^{1}$ German initials of National Socialist German Workers' Party, commonly referred to as the Nazi party.
} 


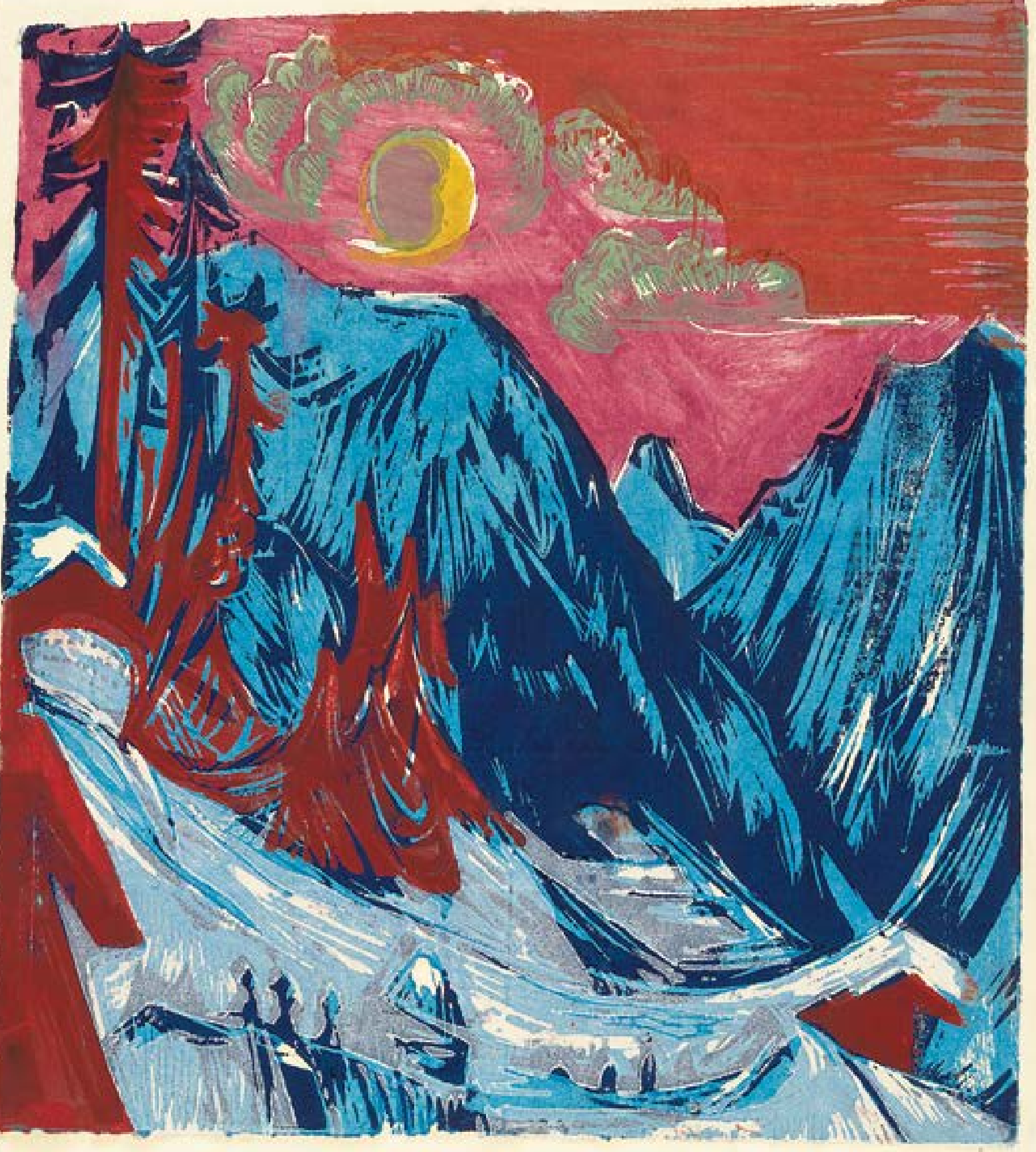

Ernst Ludwig Kirchner. Winter Landscape in Moonlight, 1919. Oil on canvas, $29.5 \times 30.5 \mathrm{~cm}$. 
the guiding science of modernism, and theology of the middle ages». Neither Mayer-Tasch nor any of the other promoters of a political ecology mentioned the existence of a political ecology in the 1930s and 40s. Likewise, although during the 1940s ethologist Konrad Lorenz, a member of the Office of Racial Policy of the NSDAP, had demanded that a «scientifically underpinned race policy» eradicate inferior elements from society (Deichmann, 1996, pp. 187-191), he was celebrated by leading representatives of the ecological movements in Germany and Austria in the 1970s as one of their mentors regarding the preservation of nature and protection of life. In his book Die acht Todsünden der zivilisierten Menschheit, published in 1973 and translated to English one year later as Civilized man's eight deadly sins, Lorenz does not mention the holocaust, a fact that prompted the American social scientist Donald Campbell to comment that «while nuclear weapons are on his list of deadly sins, genocidal nationalism was already deadly sin number one even before the atom and hydrogen bombs» (Evans, 1975, p. 1069).

The idea of modern scientific rationality that increasingly replaced folk knowledge and myths is based on the distinction between facts and values and, at its core, ideally, the independence of political currents. Disregarding this distinction led scientists to promote the idea of political ecology and to label people with alleged or real hereditary diseases or other special hereditary traits as inferior or superior. Assessments such as these are not scientific but result only from ideologies. The demand of the future Nobel laureate Konrad Lorenz during the years 1940-43 that a «scientifically underpinned race policy» eradicate inferior elements from society, was one of the worst prostitutions of biologists in the service of the Nazi race policy at the time.

A study of history shows how each generation tends to forget those actions of its forbears that do not fit in with prevailing perspectives. In the context of our own times, the reemergence of the nation state and the decline of a liberal, international order, bolstered by misinformation and nationalist doctrines, are already chipping away at value neutrality in the pursuit of knowledge. It behooves us to remember that the anti-scientific or overly science-sceptic stances and actions they encourage do not lead to a better and more ethical science. On the contrary, they contribute to irrationalism and post-truth attitudes and the dangers to science and to human kind that they entail. ()

\section{REFERENCES}

Bergmann, B., Epple, M., \& Ungar, R. (Eds.). (2012). Transcending tradition. Jewish mathematicians in German speaking academic culture. Heidelberg: Springer. doi: 10.1007/978-3-642-22464-5

Beyerchen, A. D. (1997). Scientists under Hitler: Politics and the physics community in the Third Reich. New Haven: Yale University Press.

Bramwell, A. (1985). Blood and soil: Richard Walther Darré and Hitler's

'Green Party'. Bourne End, Buckinghamshire: Kensal.

Charpa, U., \& Deichmann, U. (2007). Jews and sciences in German contexts. Case studies from the 19th and 20th centuries. Tübingen: MohrSiebeck.

Deichmann, U. (1996). Biologists under Hitler. Cambridge/London: Harvard University Press.

Deichmann, U. (1999). The expulsion of Jewish chemists and biochemists from academia in Nazi Germany. Perspectives on Science, 7(1), 1-86. doi: 10.1162/posc.1999.7.1.1

Deichmann, U. (2000). An unholy alliance. The Nazis showed that "politically responsible" science risks losing its soul. Millenium-essay. Nature, 405, 739. doi: 10.1038/35015633

Deichmann, U. (2001). Flüchten, Mitmachen, Vergessen. Chemiker und Biochemiker im Nationalsozialismus. Weinheim: Wiley/VCH. doi: $10.1002 / 3527603026$

Deichmann, U. (2004). Politische Ökologie, biologische, chemische und medizinische Umweltforschung in der NS-Zeit. Acta Historica Leopoldina, 39, 117-134.

Evans, R. I. (1975). Konrad Lorenz: The man and his ideas. New York/London: Harcourt Brace Jovanovich.

Friederichs, K. (1934). Vom Wesen der Ökologie. Sudhoffs Archiv zur Geschichte der Naturwissenschaften, 27, 277-285

Friederichs, K. (1937). Ökologie als

Wissenschaft von der Natur. Leipzig: J.A. Barth.

Hutton, C. (2005). Race and the Third Reich: Linguistics, racial anthropology and genetics in the dialectic of Volk. Cambridge: Polity Press.

Joravsky, D. (1970). The Lysenko affair.

Chicago: University of Chicago Press

Kennedy, E. P. (2001). Hitler's gift and the era of biosynthesis.

Journal of Biological Chemistry, 276, 42619-42631. doi: 10.1074/jbc.R100051200

Mayer-Tasch, P. C. (1985). Aus dem Wörterbuch der politischen Ökologie. Munich: Dt. Taschenbuch-Verlag.

Müller-Hill, B. (1988). Murderous science: Elimination by scientific selection of Jews, Gypsies, and others, Germany 1933-1945. Oxford: Oxford University Press.

Sussman, R. W. (2014). The myth of race: The troubling persistence of an unscientific idea. Cambridge/London: Harvard University Press.

Trepl, L. (1987). Geschichte der Ökologie: vom 17. Jahrhundert bis zur Gegewart: zehn Vorlesungen (Vol. 4070). Frankfurt: Athenäum.

Weber, H. (1935). Lage und Aufgabe der Biologie in der deutschen Gegenwart. Zeitschrift für die gesamte Naturwissenschaft, 1,95-106.

Weber, H. (1942). Organismus und Umwelt. Der Biologe, 11, S. 57.

Wetzell, R. (2017). Eugenics, racial science, and Nazi biopolitics. In D. Pendas, M. Roseman, \& R. Wetzell (Eds.), Beyond the racial state: Rethinking Nazi Germany (pp. 147-175). Cambridge: Cambridge University Press. doi: 10.1017/9781316691700.006

UTE DEICHMANN. Director of the Jacques Loeb Centre for the History and Philosophy of the Life Sciences, Ben-Gurion University of the Negev (Israel), and adjunct professor at this university and the University of Cologne (Germany). Her research is on the origin and change of modern biology concepts and on the impact of various ideologies on science. Recent publications include: Epigenetics: The origin and evolution of a fashionable topic and Biologists under Hitler. For her work she was awarded several prizes, such as the Ladislaus Laszt Awart of the BenGurion University and the Gmelin-Beilstein Memorial Medal of the German Chemical Society. $\square$ uted@post.bgu.ac.il 